\title{
The Metabolism of Starch, Glucose, Amino Acids, Purines, Pyrimidines and Bacteria by Three Epidinium spp. Isolated from the Rumen
}

\author{
By G. S. COLEMAN AND JUDITH I. LAURIE \\ Agricultural Research Council Institute of Animal Physiology, Babraham, \\ Cambridge $C B 24 A T$
}

(Received 9 April 1974; revised 26 July 1974)

SUMMARY

\begin{abstract}
Washed suspensions of Epidinium spp. grown in vitro and incubated anaerobically in salts medium engulfed all the bacteria tested at rates ranging from 60 to $7000 /$ protozoon $/ \mathrm{h}$ at a density of $10^{9} / \mathrm{ml}$. The rate of uptake of bacteria was also compared by the volume of medium cleared of bacteria/h. On both bases Proteus mirabilis was taken up most rapidly. Some of the bacteria were killed and digested inside the protozoa. The Epidinium spp. took up a wide range of amino acids at rates varying from 6 to $250 \mathrm{nmol} / 10^{6}$ protozoa/h and incorporated them into protein, mostly without conversion to other amino acids. The protozoa also incorporated purines and pyrimidines into nucleic acid and interconverted adenine and guanine and also uracil and cytosine.

Epidinium ecaudatum caudatum took up $\left[{ }^{14} \mathrm{C}\right] \mathrm{glucose}$ more rapidly than Entodinium caudatum and used the glucose carbon for the synthesis of an intracellular glucose polysaccharide and at least eight amino acids, $15 \%$ of the ${ }^{14} \mathrm{C}$ in the protozoa appearing in protein. The protozoa also synthesized protein from starch grains. Evidence has been obtained that Epi. ecaudatum caudatum cannot obtain all the protein it requires for growth from bacteria, free amino acids, glucose or starch and must incorporate protein from the wholemeal flour on which it is grown.
\end{abstract}

\section{INTRODUCTION}

Although Epidinium spp. are important members of the B-type of rumen population (Eadie, 1962, 1967), especially in New Zealand cows (Clarke, 1964), there have been few studies on their metabolism. Oxford (1959) found that an Epidinium sp. isolated from crude rumen contents utilized glucose and, to a lesser extent, fructose to form an amylopectin-like polysaccharide and that these sugars prolonged the life of starved protozoa. Epidinium ecaudatum caudatum grown in vitro produced gas from various starch-containing materials used to feed ruminants and incorporated ${ }^{14} \mathrm{C}$-labelled amino acids (Gutierrez \& Davis, 1962). The only other investigations on Epidinium spp. have been on the carbohydrases of extracts of these protozoa isolated from the rumen (e.g. Bailey \& Gaillard, 1965).

We have investigated the metabolic capabilities of Epidinium spp., especially the ovine form of Epi. ecaudatum caudatum grown in vitro (Coleman, Davies \& Cash, 1972), in order to determine if these protozoa could synthesize amino acids, purines and pyrimidines and to determine if engulfed bacteria were important sources of these compounds. A preliminary report of this work has already appeared (Coleman, 1973). 


\section{METHODS}

Epidinium ecaudatum caudatum (ovine) was first isolated from the rumen and cultured from a single protozoon in July 1969 by the methods described by Coleman et al. (I972). This culture survived until November 1970. A new culture was then initiated from a single protozoon and this survived until November 1972. The third culture, begun at this time, was still growing well at the time of writing (December 1973). The experiments described were carried out continuously over these years and where two different isolates had to be used because one had died, care was taken to check that the behaviour of the two was the same. As far as could be determined all three isolates behaved similarly. The bovine form of Epi. ecaudatum caudatum and Epi. ecaudatum tricaudatum were as described by Coleman et al. (1972).

Sonicated bacteria or broken protozoal pellets were prepared by treatment with a Mullard/MSE ultrasonic drill (type $7685 / 2$ ), with the $20 \mathrm{~mm}$ diam probe just touching the surface of $2 \mathrm{ml}$ suspension in a $50 \mathrm{ml}$ beaker surrounded by ice.

Protein estimations were made by the method of Lowry, Rosebrough, Farr \& Randall (1951). Other techniques have been described by Coleman (1956, 1967a, $b, \mathrm{I} 968, \mathrm{I} 969 a, b$, 1972) and Coleman et al. (1972). Mineral salt solution D (Coleman, 1972) was used throughout; only protozoa showing no sign of disintegration were counted.

\section{RESULTS}

Bacteria associated with suspensions of Epi. ecaudatum caudatum (ovine)

In a standard washed suspension of Epi. ecaudatum caudatum (ovine) there were ten viable bacteria free in the medium above each protozoon after allowing the protozoa to sink to the bottom of the tube under gravity for $5 \mathrm{~min}, 25$ bacteria/protozoon after mixing the suspension and 130 bacteria/protozoon after sonication of the suspension to disrupt the protozoa but not the bacteria. This means that there were 15 bacteria associated with intact protozoa probably attached to other particulate matter in the preparation and that there were approximately Ioo viable bacteria closely associated with each freshly harvested protozoon. This number did not alter on incubation of the Epidinium in salt soln D for $5 \mathrm{~h}$ but dropped to 25 when I $\mathrm{mg}$ ampicillin/ml was added to the medium.

\section{The metabolism of bacteria}

Epidinium spp. engulfed all bacteria for at least $\mathrm{I} h$ on addition of ${ }^{14} \mathrm{C}$-labelled bacteria to a protozoal suspension, although the number of bacteria found inside each protozoon varied markedly with the bacterial species being studied and the length of time that the Epidinium sp. had been in culture. Epidinium ecaudatum caudatum (ovine) took up bacteria seven to eight times as fast after 20 months in culture as it did on initial isolation.

The optimum $\mathrm{pH}$ value for bacterial uptake was from $6 \cdot 3$ to $7 \cdot 8$ with the uptake declining to nil at $\mathrm{pH} 5 \cdot \mathrm{I}$ when the protozoa were dead. The optimum salt concn was from 60 to I $15 \%$ of that in salt soln D (Coleman, I972).

Comparison of the rate of engulfment of different bacterial species. This was made on the basis of the number of bacteria taken up per protozoon at an infinitely high bacterial suspension density and at $10^{9}$ bacteria $/ \mathrm{ml}$, and of the volume of medium cleared of bacteria by each protozoon from an infinitely dilute bacterial suspension and from a suspension of $10^{9}$ bacteria/ml, as described by Coleman (1972). 
Table I. The uptake of bacteria by three Epidinium spp.

The maximum number of bacteria engulfed is the number taken up from an infinitely dense bacterial suspension. The maximum volume cleared of bacteria is the volume cleared when the bacterial suspension was infinitely dilute.

\begin{tabular}{|c|c|c|c|c|c|}
\hline \multirow[b]{2}{*}{ Bacterium } & \multirow[b]{2}{*}{$\begin{array}{l}\text { Volume of } \\
\text { bacterium* }\end{array}$} & \multicolumn{2}{|c|}{$\begin{array}{c}\text { Bacteria } \\
\text { engulfed/protozoon/h* }\end{array}$} & \multicolumn{2}{|c|}{$\begin{array}{c}{ }^{10^{-6}} \times \text { Volume cleared of } \\
\text { bacteria/protozoon/h* }\end{array}$} \\
\hline & & Maximum & $\begin{array}{c}\text { At } 10^{9} \\
\text { bacteria } / \mathrm{ml}\end{array}$ & $\underset{\left(\mu \mathrm{m}^{3}\right)}{\operatorname{Maximum}}$ & $\begin{array}{l}\text { At } \mathrm{IO}^{9} \\
\text { bacteria } / \mathrm{ml} \\
\left(\mu \mathrm{m}^{3}\right)\end{array}$ \\
\hline \multicolumn{6}{|c|}{ Epidinium ecaudatum caudatum (ovine) } \\
\hline Bacillus megaterium & 20 & 400 & 260 & 0.6 & 0.25 \\
\hline B. subtilis & & 830 & 440 & 0.9 & 0.42 \\
\hline Butyrivibrio fibrisolvens & $I \cdot 0$ & 1430 & 320 & $I \cdot 9$ & $I \cdot 3$ \\
\hline Escherichia coli & $1 \cdot 4$ & I 870 & 770 & $I \cdot 2$ & 0.73 \\
\hline Klebsiella aerogenes & $1 \cdot 8$ & 260 & 60 & $0 \cdot \mathbf{I}$ & 0.07 \\
\hline Lactobacillus casei & $3 \cdot 3$ & I 320 & 440 & 0.6 & 0.25 \\
\hline Micrococcus lysodeikticus & & 460 & 250 & 0.9 & 0.24 \\
\hline Proteus mirabilis & $\mathrm{I} \cdot 8$ & 121000 & 6600 & $5 \cdot 2$ & $5 \cdot 1$ \\
\hline P. vulgaris & $\mathrm{I} \cdot 8$ & II 000 & I 380 & $\mathrm{I} \cdot \mathrm{I}$ & 0.9 \\
\hline Pseudomonas aeruginosa & $2 \cdot 2$ & 6800 & 5500 & $8 \cdot 3$ & $6 \cdot 7$ \\
\hline Saccharomyces fragilis & 30 & 1400 & I 260 & 16 & 0.72 \\
\hline Streptococcus bovis & $2 \cdot 0$ & 420 & 170 & 0.3 & 0.17 \\
\hline Torulopsis glabrata & $8 \cdot 5$ & 1400 & 420 & 0.97 & 0.44 \\
\hline Mixed rumen bacteria & & 10100 & 3600 & $8 \cdot 7$ & $6 \cdot 8$ \\
\hline \multicolumn{6}{|c|}{ Epi. ecaudatum caudatum (bovine) } \\
\hline B. megaterium & 20 & 380 & 310 & $2 \cdot 4$ & 0.38 \\
\hline Butyrivibrio fibrisolvens & $I \cdot O$ & 1700 & I IOO & $4 \cdot 5$ & 0.7 \\
\hline E. coli & $I \cdot 4$ & 480 & 310 & $\mathrm{I} \cdot \mathrm{I}$ & 0.3 \\
\hline$K$. aerogenes & $1 \cdot 8$ & 420 & 280 & $\mathrm{I} \cdot 0$ & 0.36 \\
\hline P. mirabilis & $\mathrm{I} \cdot 8$ & $\infty$ & 4700 & $5 \cdot \mathrm{I}$ & $5 \cdot 5$ \\
\hline Mixed rumen bacteria & & 16000 & 5600 & 23 & $4 \cdot 7$ \\
\hline \multicolumn{6}{|l|}{ Epi. ecaudatum tricaudatum } \\
\hline B. megaterium & 20 & 16 & I4 & 0.60 & 0.14 \\
\hline Butyrivibrio fibrisolvens & $I \cdot 0$ & 220 & 190 & $2 \cdot 4$ & 0.17 \\
\hline E. coli & $1 \cdot 4$ & 1100 & 210 & 0.30 & 0.19 \\
\hline$K$. aerogenes & $1 \cdot 8$ & 260 & 88 & 0.17 & 0.08 \\
\hline P. mirabilis & $\mathrm{I} \cdot 8$ & 1670 & 350 & 0.75 & $0 \cdot 36$ \\
\hline Mixed rumen bacteria & & 5000 & 3200 & $6 \cdot 0$ & $2 \cdot 6$ \\
\hline
\end{tabular}

* Determined as described by Coleman (1972).

Table I shows a series of results obtained with the ovine and bovine forms of Epi.ecaudatum caudatum and with Epi. ecaudatum tricaudatum, 6 to 12 months after the isolation of the culture. There was nearly a 500-fold variation between different bacterial species in the maximum number of bacteria engulfed, and a 50-fold variation in the maximum volume of medium cleared of bacteria. This result contrasts markedly with those obtained with Entodinium caudatum and Ento. simplex (Coleman, 1964, 1972) where the volume of medium cleared was almost the same for all bacterial species tested, and where the number of bacteria taken up was inversely related to the size of the bacterium.

With Proteus mirabilis, the uptake of bacteria was proportional to the bacterial population density, and the volume of medium cleared was almost independent of the number of bacteria present. This can be deduced from Table $\mathrm{I}$, where the volume of medium cleared is almost the same at infinite dilution and at $10^{9}$ bacteria $/ \mathrm{ml}$. In contrast, when the population density of the yeast Saccharomyces fragilis was increased from $10^{8}$ to $10^{9} / \mathrm{ml}$, the number of organisms engulfed increased only $I \cdot 9$ times, whereas the volume of medium cleared 
decreased by $83 \%$. Epidinium ecaudatum caudatum (ovine) either removes all the yeasts from the medium that passes into its oesophagus but decreases this volume at high yeast population densities, or always passes the same volume of medium but becomes less efficient at removing the yeasts at high densities. With $P$. mirabilis the protozoon could have removed all the organisms from the same volume of medium at all bacterial densities. However, if it is assumed that the maximum clearance of medium given in Table $I$ is the actual amount of medium that passes, and that it is constant, then only $30 \%$ of the $P$. mirabilis organisms can have been removed from this medium. The kinetics of the engulfment of the other yeasts and bacteria lay between these two extremes.

As there was such a large variation between the rate at which the different bacterial species were taken up by the Epidinium spp. with no uniform difference between those of rumen origin (Butyrivibrio fibrisolvens and Streptococcus bovis) or those found in protozoal cultures (Klebsiella aerogenes and Proteus mirabilis) (White, 1969) and bacteria isolated from elsewhere, an attempt was made to investigate the uptake of mixed bacteria from the rumen. These were labelled with ${ }^{35} \mathrm{~S}$ by growth in sulphur-deficient media containing $\left.{ }^{35} \mathrm{~S}\right]$ sulphate using the method of Bird (I972). If we assume that the bacteria in these preparations were equally labelled with ${ }^{35} \mathrm{~S}$ (there is no evidence on this) then the number of bacteria taken up can be calculated as before. Mixed rumen bacteria were taken up more rapidly by the three Epidinium spp. than bacteria from most of the pure cultures (Table I).

Effect of physical form on the uptake of bacteria. Sonication of a suspension of ${ }^{14} \mathrm{C}$-labelled $E$. coli for $0.5, \mathrm{I}, 2,3,5$ or $10 \mathrm{~min}$ before incubation with the protozoon resulted in uptakes of ${ }^{14} \mathrm{C}$ of $2 \cdot 7,3 \cdot 9,4 \cdot 8,4 \cdot 9,4 \cdot 9$ and $5 \cdot 2$ times that of the untreated suspension (taken as I). As sonication for 3 min produced an almost completely clear solution, the Epi. ecaudatum caudatum (ovine) took up a greater mass of material in the form of small particles than as intact bacteria. In contrast, sonication of Proteus mirabilis or mixed rumen bacteria decreased the maximum number of bacteria engulfed by $97 \%$ and $5 \%$, respectively, although with $P$. mirabilis the treatment had much less effect on the maximum volume cleared at infinite dilution.

To determine if this increased uptake of $E$. coli on sonication was due to a general stimulation of the feeding process or a specific liking of the Epidinium sp. for sonicated $E$. coli, the effect of sonicated ${ }^{12} \mathrm{C}$-labelled $E$. coli or $P$. mirabilis on the uptake of intact ${ }^{14} \mathrm{C}$-labelled $E$. coli or $P$. mirabilis was investigated. The added ${ }^{12} \mathrm{C}$-labelled material decreased the uptake of ${ }^{14} \mathrm{C}$ by the Epidinium sp., indicating that sonicated $E$. coli does not stimulate the feeding process.

Viability of engulfed bacteria. Over $90 \%$ of the bacteria engulfed from suspensions of pure cultures of the Gram-negative bacteria listed in Table I, during a I h incubation, were still viable at the end. This contrasts with the results obtained with Ento. caudatum and Ento. simplex (Coleman, 1967b, 1972), where there was considerable variation between different Gram-negative bacteria. No viable Bacillus megaterium or B. subtilis was found inside Epi. ecaudatum caudatum (ovine) on incubation with suspensions of these bacteria.

The digestion of bacteria. By measuring the rate at which soluble ${ }^{14} \mathrm{C}$-labelled compounds appeared in the medium on incubation of Epidinium spp. with ${ }^{14} \mathrm{C}$-labelled bacteria, the organisms listed in Table I could be divided into two groups based on whether or not bacterial digestion products were liberated rapidly into the medium.

On incubation of any of the three Epidinium spp. with bacteria of the first group, B. megaterium, B. subtilis and Micrococcus lysodeikticus, 20 to 40 times as many bacteria were digested in $30 \mathrm{~min}$ as were found inside the protozoa at that time (Coleman \& Laurie, 1974). With organisms of the second group, which contained all the others given in Table I, no 
bacterial carbon was released into the medium and digestion was followed by the appearance of ${ }^{14} \mathrm{C}$ from ${ }^{14} \mathrm{C}$-labelled bacteria in the protozoal broken-cell supernatant fluid. Using this criterion all the bacteria tested, including the mixed rumen bacteria but not Streptococcus faecalis or Klebsiella aerogenes, were digested slowly by the three Epidinium spp. With $P$. mirabilis digestion of bacteria by Epi. ecaudatum caudatum (ovine) took from 60 to $250 \mathrm{~min}$, although after $320 \mathrm{~min}$ incubation $80 \%$ of the bacterial carbon was present in the broken-cell supernatant fluid.

\section{The metabolism of free amino acids}

When Epidinium spp. were incubated anaerobically with free amino acids, the amino acids were taken up progressively by the protozoa and incorporated into cellular constituents. With [U-14 C]glycine, in the presence of Epi. ecaudatum caudatum (ovine), 60 to $70 \%$ of the incorporated ${ }^{14} \mathrm{C}$ was found in the protozoal broken-cell supernatant fluid and of this 30 to $40 \%$ was present in the trichloracetic acid (TCA)-soluble pool and approximately $40 \%$ in the protein. Unfortunately the Epidinium spp. had bacteria attached to the outside of the pellicle and in the endoplasm (Coleman \& Hall, 1974) so it was possible that the incorporation into the broken-cell pellet fraction was into these bacteria and not into protozoal material.

After $5 \mathrm{~h}$ incubation with intact protozoa, ampicillin $(\mathrm{I} \mathrm{mg} / \mathrm{ml})$ had no effect on the incorporation of ${ }^{14} \mathrm{C}$ into the broken-cell supernatant fluid, but decreased incorporation into the broken-cell pellet by $17 \%$. Sonication of the protozoa (to release the associated bacteria) before incubation with the ${ }^{14} \mathrm{C}$-labelled amino acid increased incorporation into the broken-cell pellet fraction three to four times, but ampicillin decreased this by $94 \%$. These results show that most of the bacteria that incorporated ${ }^{14} \mathrm{C}$ were not readily accessible to the amino acid or ampicillin in intact protozoa and were probably in the endoplasm rather than attached to the outside of the pellicle.

Table 2 shows the rate of uptake by the three Epidinium spp. and Ento. caudatum of 13 amino acids present at $0.1 \mathrm{mM}$, the order of concentration at which they are found in the rumen (Wright \& Hungate, 1967). All the amino acids tested were taken up by the Epidinium spp. Epidinium ecaudatum caudatum (ovine), which had the slowest rate of the three protozoa, took up amino acids on average at eight times (range: 2.5 times with leucine to 25 times with alanine) the rate with Ento. caudatum. As the Epidinium spp. had 5.5 times the volume and 3.3 times the area of Ento. caudatum (calculated from the measured length and diameter and assuming each to be cylindrical), these results show that the Epidinium spp. take up amino acids more rapidly per unit volume or area than does Ento. caudatum.

On a reciprocal plot of amino acid uptake by Epi. ecaudatum caudatum (ovine) against amino acid concentration, there was a break in the curve for all amino acids at about $2 \mathrm{~mm}$ except for glycine where it was at $6 \mathrm{~mm}$. This Epidinium therefore resembles Ento. simplex (Coleman, 1972) rather than Ento. caudatum (Coleman, 1967a) with which the amino acids could be divided into two groups based on the position of the break in the curve. Similarly the maximum rates of uptake at infinite amino acid concentration, calculated by extrapolation of the right-hand part of the curve to the ordinate (Coleman, 1967a), did not fall into two groups, but ranged from $0.039 \mu \mathrm{mol} / \mathrm{h} / \mathrm{IO}^{6}$ protozoa with valine to $0.45 \mu \mathrm{mol} / \mathrm{h} / \mathrm{IO}^{6}$ protozoa with glycine. The left-hand part of the curve always passed through or near the origin. With $\left[{ }^{14} \mathrm{C}\right]$ phenylalanine in the presence of $p$-fluorophenylanine, an inhibitor of phenylalanine metabolism, there was no discontinuity in the curve which passed through the origin with a similar slope to that of the left-hand part of the original curve. By similar arguments to those used previously (Coleman, $1967 a$ ) these results suggest that amino acids 
Table 2. The uptake of free amino acids by Ento. caudatum and three species of Epidinium

Protozoa were incubated anaerobically in salt solution containing the amino acid under investigation at $\mathrm{O} . \mathrm{I} \mathrm{mM}$ for $2 \mathrm{~h}$ when the protozoa were washed and the uptake of ${ }^{14} \mathrm{C}$ measured. The amount of amino acid taken up was calculated from the ${ }^{14} \mathrm{C}$ content and the known specific activity of the amino acid added. The number of protozoa present in $\mathrm{I} \mathrm{ml} \mathrm{incubation} \mathrm{mixture} \mathrm{was:} \mathrm{Ento.}$ caudatum, $225000 / \mathrm{ml}$, Epi. ecaudatum caudatum (ovine) $10400 / \mathrm{ml}$, Epi. ecaudatum caudatum (bovine) ${ }_{11} 40 / \mathrm{ml}$, Epi. ecaudatum tricaudatum, $3500 / \mathrm{ml}$. The results are expressed in $\mathrm{nmol} / \mathrm{h} / 10^{6}$ protozoa.

\begin{tabular}{|c|c|c|c|c|}
\hline & $\begin{array}{c}\text { Ento. } \\
\text { caudatum }\end{array}$ & $\begin{array}{c}\text { Epi. } \\
\text { ecaudatum } \\
\text { caudatum } \\
\text { (ovine) }\end{array}$ & $\begin{array}{c}\text { Epi. } \\
\text { ecaudatum } \\
\text { caudatum } \\
\text { (bovine) }\end{array}$ & $\begin{array}{c}\text { Epi. } \\
\text { ecaudatum } \\
\text { tricaudatum }\end{array}$ \\
\hline L-Ala & 0.84 & $21 \cdot 4$ & 140 & 83 \\
\hline L-Arg & $I \cdot 64$ & $12 \cdot 2$ & 248 & 39 \\
\hline L-Asp & 0.79 & $6 \cdot 2$ & I6I & 20 \\
\hline L-Glu & 1.04 & $6 \cdot 8$ & IOI & 22 \\
\hline Gly & $6 \cdot 5$ & $78 \cdot 4$ & 192 & 23 \\
\hline L-Ile & $3 \cdot 2$ & $9 \cdot 6$ & IOI & 105 \\
\hline L-Leu & $3 \cdot 2$ & 8.0 & - & - \\
\hline L-Lys & I. 9 & $12 \cdot 2$ & 135 & I3 \\
\hline L-Met & $2 \cdot 2$ & 6.8 & IOI & 65 \\
\hline L-Phe & $2 \cdot I$ & $8 \cdot 2$ & 65 & 178 \\
\hline L-Pro & 2.5 & 19.2 & 130 & 126 \\
\hline L-Ser & $I \cdot 6$ & $24 \cdot 2$ & 490 & $6 I$ \\
\hline L-Val & $2 \cdot 3$ & $8 \cdot 8$ & IOI & 22 \\
\hline
\end{tabular}

Table 3. Products of the metabolism of free amino acids by Epi. ecaudatum caudatum (ovine)

Protozoa were incubated in Conway units (Conway, 1947) under $\mathrm{N}_{2}$ for $2 \mathrm{~h}$ with one ${ }^{14} \mathrm{C}$-labelled amino acid. Products were measured in the external medium. ${ }^{14} \mathrm{CO}_{2}$ was estimated after the addition of $\mathrm{HCl}$ (Coleman, 1956). ${ }^{14} \mathrm{C}$-labelled volatile acid was retained on a planchet in the presence of alkali but lost in the presence of acid. The results are expressed in mol/ $100 \mathrm{~mol}$ carbon incorporated.

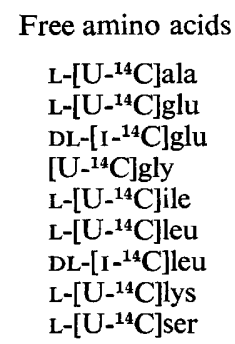

$\begin{array}{cr}{ }_{\text {Volatile acid }}^{{ }^{14} \mathrm{C} \text { recovered in: }} \\ 0 & \mathrm{CO}_{2} \\ 63 & 440 \\ 500 & 440 \\ 25 & 2800 \\ 0 & 177 \\ 34 & 40 \\ 53 & 20 \\ 0 & 46 \\ 180 & 68 \\ & 460\end{array}$

enter the protozoa by an 'active' and a passive process, the former being predominant at low external concentrations and the latter predominant at high concentrations.

Extracellular products of amino acid metabolism. Table 3 shows that with Epi. ecaudatum caudatum (ovine), all the free amino acids tested were catabolized to some extent and that $\mathrm{CO}_{2}$ was the principal product. However, the relative proportions catabolized or assimilated varied considerably between amino acids. Where the metabolism of $\mathrm{I}^{14} \mathrm{C}$ - and $\mathrm{U}-{ }^{14} \mathrm{C}$-labelled leucine and glutamic acid were compared, a greater proportion of the ${ }^{14} \mathrm{C}$ was liberated as ${ }^{14} \mathrm{CO}_{2}$ with the former than the latter, suggesting that the carboxyl carbon was preferentially liberated as $\mathrm{CO}_{2}$. Similar results were obtained with Epi. ecaudatum tricaudatum. 
Intracellular products of amino acid metabolism. Of the amino acid carbon taken up by the Epidinium spp., 5I to $69 \%$ was found in the broken-cell supernatant fluid and of this 30 to $40 \%$ was present in the pool. Of the remaining material in the broken-cell supernatant fluid, over $90 \%$ was present in the protein fractions. To determine whether there had been interconversion between the amino acids, the residual protein fractions of the broken-cell supernatant fluid and pellet fractions were hydrolysed, the amino acids chromatographed on paper in two dimensions and autoradiograms prepared. With the protein of the brokencell supernatant fluid there was only one ${ }^{14} \mathrm{C}$ spot with ${ }^{14} \mathrm{C}$-labelled alanine, glutamic acid, glycine, leucine, lysine and phenylalanine and this chromatographed in the same place as the original ${ }^{14} \mathrm{C}$-labelled amino acid. However, ${ }^{14} \mathrm{C}$ from labelled serine was also incorporated into the following amino acids (with the amount of each relative to that found in serine, which was taken as 1$)$ : alanine $(0.27)$, aspartic acid (0.07), cysteine (0.24), glutamic acid (0.I6), glycine (0.I8), leucine plus isoleucine plus phenylalanine $(0 \cdot 07)$, lysine $(0 \cdot 1 \mathrm{I})$ and valine $\left(0 \cdot \mathrm{I}_{3}\right) .\left[{ }^{14} \mathrm{C}\right]$ aspartic acid was even more extensively metabolized and ${ }^{14} \mathrm{C}$ was found in the following (aspartic acid taken as I): alanine (0.56), arginine $(0.43)$, glutamic acid $(0.68)$, glycine (0.13), leucine plus isoleucine plus phenylalanine $(0.42)$, lysine $(0.57)$, proline $(0.28)$, threonine $(0.55)$ and valine $(0.25)$. Similar results were obtained with protein from the broken-cell pellet fraction except that with some of the first group of ${ }^{14} \mathrm{C}$-labelled amino acids there were other minor spots present.

\section{The metabolism of free purines and pyrimidines}

Intracellular products of metabolism. In $200 \mathrm{~min} 20 \%$ of the adenine, $12 \%$ of the guanine and $6 \%$ of the uracil were incorporated by the protozoa. Of this, over $80 \%$ was present in the broken-cell supernatant fluid, indicating that the bacteria, associated with the protozoa and sedimented in the broken-cell pellet fraction, were unlikely to have been important in these incorporations. Of the ${ }^{14} \mathrm{C}$ in the broken-cell supernatant fluid, 35 to $75 \%$ was in the pool and only 7 to I $8 \%$ in the 'hot' TCA-soluble or nucleic acid fraction. In the presence of $\left[{ }^{14} \mathrm{C}\right]$ adenine, $66 \%$ of the ${ }^{14} \mathrm{C}$ in this latter fraction was present as adenine and $34 \%$ as guanine; with $\left.{ }^{14} \mathrm{C}\right]$ guanine $16 \%$ was present as adenine and $84 \%$ as guanine; and with $\left[{ }^{14} \mathrm{C}\right]$ uracil $66 \%$ was present as uracil and $34 \%$ as cytosine.

Extracellular products of metabolism. With Epi. ecaudatum caudatum (ovine) both purines disappeared rapidly from the medium, less than $5 \%$ remaining after $6 \mathrm{~h}$. On addition of $\left[8{ }^{14} \mathrm{C}\right]$ adenine to the protozoal suspension, $\left[{ }^{14} \mathrm{C}\right] \mathrm{xanthine}$ and $\left[{ }^{14} \mathrm{C}\right]$ hypoxanthine appeared within $5 \mathrm{~min}$ and the amount of each increased in parallel to a maximum after $6 \mathrm{~h}$ (I 3 to $15 \%$ of the original ${ }^{14} \mathrm{C}$ in each compound). Thereafter, the amount of both compounds declined, the hypoxanthine disappearing after $24 \mathrm{~h}$ and the xanthine after $48 \mathrm{~h}$. Similar results were obtained with $\left[8-{ }^{14} \mathrm{C}\right]$ guanine except that, at the maximum, $40 \%$ of the ${ }^{14} \mathrm{C}$ was present as xanthine and only $3 \%$ as hypoxanthine. However, with both purines there was a steady decline in the amount of ${ }^{14} \mathrm{C}$ found on the chromatogram, with less than $5 \%$ of the original ${ }^{14} \mathrm{C}$ remaining after $48 \mathrm{~h}$. As this missing ${ }^{14} \mathrm{C}$ was not present in the protozoa, a volatile compound must have been produced which, as it was not retained on a planchet even by the addition of $\mathrm{NaOH}$, is assumed to be $\mathrm{CO}_{2}$. The rate of metabolism of the purines was unaffected by $800 \mu \mathrm{g}$ ampicillin/ml, indicating that extracellular bacteria were not responsible. Guanine and adenine were probably converted to xanthine and hypoxanthine, respectively, and the latter was readily converted to the former; the opposite reaction was very slow. The xanthine was further metabolized in such a way that C-8 was converted to $\mathrm{CO}_{2}$. This would occur if the breakdown occurred by way of uric acid, allantoin, allantoic acid and urea as in many lower organisms (Florkin \& Duchateau-Bosson, 1943). None of these 


\section{Table 4. Metabolism of $\left[{ }^{14} \mathrm{C}\right]$ starch grains by Epi. ecaudatum caudatum}

Protozoa were incubated anaerobically at $39{ }^{\circ} \mathrm{C}$ with $3.0 \mu \mathrm{Ci}\left[{ }^{14} \mathrm{C}\right]$ starch grains. Fifty thousand washed protozoa were suspended in $2.2 \mathrm{ml}$ salts medium (containing $\mathrm{I} \mathrm{mg}$ ampicillin $/ \mathrm{ml}$ in tube 2 ). Tube I was incubated for $6 \mathrm{~h}$ and Tube 2 for $29 \mathrm{~h}$. The protozoa were washed, broken by sonication and the supernatant fluid and pellet fractions separated by centrifuging.

Non-volatile soluble material in medium

Volatile acid

Cold TCA-soluble material Hot TCA-soluble material Residual protein
Radioactivity (\% of ${ }^{14} \mathrm{C}$ added initially)

\begin{tabular}{|c|c|c|c|c|}
\hline No protozoa & \multicolumn{2}{|c|}{ Tube I } & \multicolumn{2}{|c|}{ Tube 2} \\
\hline$I \cdot I$ & \multicolumn{2}{|c|}{$13 \cdot 7$} & \multicolumn{2}{|c|}{$28 \cdot 4$} \\
\hline 0.55 & \multicolumn{2}{|c|}{$20 \cdot 6$} & \multicolumn{2}{|c|}{$20 \cdot 0$} \\
\hline $\begin{array}{l}\text { Initial } \\
\text { starch }\end{array}$ & $\begin{array}{l}\text { Supernatant } \\
\text { fluid }\end{array}$ & Pellet & $\begin{array}{l}\text { Supernatant } \\
\text { fluid }\end{array}$ & Pellet \\
\hline $4 \cdot 8$ & 0.85 & 0.22 & 0.27 & O.II \\
\hline 89 & $0.1 \mathrm{I}$ & $2 \cdot 9$ & O.II & $I \cdot 2$ \\
\hline $2 \cdot 4$ & 0.15 & 0.26 & 0.15 & 0.13 \\
\hline
\end{tabular}

intermediates were found in the medium although traces of ${ }^{14} \mathrm{C}$-labelled material that chromatographed next to marker allantoin and allantoic acid in isobutyric acid-0.6 N$\mathrm{NH}_{4} \mathrm{OH}(5: 3$ by vol) were found in some media.

\section{Metabolism of $\left[{ }^{14} \mathrm{C}\right]$ starch grains}

The metabolism of starch grains by washed suspensions of Epi. ecaudatum caudatum (ovine) was investigated using $\left[{ }^{14} \mathrm{C}\right]$ starch grains prepared from holotrich protozoa by the method of Coleman ( $1969 b)$.

The distribution of ${ }^{14} \mathrm{C}$ was similar in short experiments in the absence of ampicillin and in longer experiments in its presence, over $60 \%$ of the ${ }^{14} \mathrm{C}$ being found in the 'hot' TCAsoluble fraction of the broken-cell pellet (Table 4). This pellet contained unmetabolized starch grains, the protozoal polysaccharide granules and any associated bacteria. On hydrolysis of this 'hot' TCA-soluble material in I $\mathrm{M}-\mathrm{HCl}$ for $\mathrm{I} h$ at $100{ }^{\circ} \mathrm{C}$, the only ${ }^{14} \mathrm{C}$-compound present was $\left[{ }^{14} \mathrm{Clglucose}\right.$, indicating that most of the ${ }^{14} \mathrm{C}$-labelled material in the broken-cell pellet fraction was in the form of a glucose polysaccharide.

The main object of the experiment was to determine if this Epidinium sp. was able to synthesize protein from carbohydrate. Unfortunately the $\left[{ }^{14} \mathrm{C}\right]$ starch grains contained $0 \cdot 22 \%$ protein after papain treatment. With a washed suspension in the presence of ampicillin, $8 \%$ of the protozoal ${ }^{14} \mathrm{C}$ was present in the protein fraction of the broken-cell supernatant fluid as aspartic acid ( $39 \%$ of ${ }^{14} \mathrm{C}$ in this fraction), serine $(28 \%)$, glutamic acid $(2 \%)$, lysine $(9 \%)$ and alanine ( $18 \%$ ). A similar distribution of ${ }^{14} \mathrm{C}$ between the amino acids was found in the protein of the pellet which contained $7 \%$ of the protozoal ${ }^{14} \mathrm{C}$. In the shorter experiment in the absence of ampicillin, the same amount of ${ }^{14} \mathrm{C}$ was incorporated into the protein of the supernatant fluid but the radioactivity was distributed between alanine $(29 \%)$, aspartic acid $(28 \%$ ), glutamic acid (12\%), glycine (trace), lysine (19\%) and serine (I I \%). However, the incorporation into the protein of the broken-cell pellet was double that in the presence of ampicillin and could be the result of the synthesis of bacterial protein. The ${ }^{14} \mathrm{C}$-labelled amino acids present were alanine $(45 \%)$, aspartic acid (18\%), glutamic acid (18\%), glycine $(5 \%)$ and serine ( $14 \%)$.

There was an overall increase in the amount of ${ }^{14} \mathrm{C}$ in protein and as only certain amino acids were labelled, it is unlikely that this was the result of the engulfment of the more 
uniformly labelled protein derived from the holotrich protozoa. As $\left[{ }^{14} \mathrm{C}\right] \mathrm{glutamic}$ acid was only found in protozoa incubated without ampicillin, this could have been produced as the result of bacterial action, but it is likely that most of the alanine, serine, lysine and aspartic acid in the broken-cell supernatant fluid was synthesized from carbohydrate by the protozoa. By analogy with Ento. caudatum, in which there was little biosynthesis of amino acids (Coleman, I969 $b$ ) and 50 to $60 \%$ of the ${ }^{14} \mathrm{C}$ incorporated from free amino acids or bacteria was found in the broken-cell pellet, at least some of the ${ }^{14} \mathrm{C}$ in this fraction of Epidinium was probably also of protozoal origin.

\section{Metabolism of $\left[U-{ }^{14} C\right]$ glucose}

Sonication of the protozoa before incubation increased the incorporation of ${ }^{14} \mathrm{C}$ into the protein of the broken-cell pellet by $130 \%$ in the absence of ampicillin and decreased it to $50 \%$ in the presence of the antibiotic; ampicillin had no effect on incorporation into the broken-cell supernatant fluid. By similar arguments to those used by Coleman (I972), this is taken as evidence that incorporation into the broken-cell supernatant fluid represented uptake into protozoal material, but that incorporation into the broken-cell pellet could have been into bacteria.

Of the ${ }^{14} \mathrm{C}$ taken up by intact protozoa, the percentage present in each fraction was, in the presence and absence of $\mathrm{I} \mathrm{mg}$ ampicillin/ml: 37 and 25 in the pool; 38 and 39 in the 'hot' TCA-soluble fraction of the broken-cell pellet; 8 and 7 in the protein of the broken-cell supernatant fluid; and 6 and 15 in the protein of the broken-cell pellet. Relative to incorporation into aspartic acid in the absence of antibiotic (taken as $\mathrm{I}$ ), the following amounts of ${ }^{14} \mathrm{C}$ were found in the amino acids of the protein of the broken-cell supernatant fluid in the absence and presence of ampicillin respectively: aspartic acid, $\mathrm{I} \cdot 0, \mathrm{I} \cdot 35$; alanine, $0 \cdot 64$, $0.3 \mathrm{I}$; glutamic acid, 0.5 I, 0.2 I; glycine, trace, trace; leucine, 0.20, 0.09; lysine, 0.56, 0.54; serine, $0.21,0.3 \mathrm{I}$; valine, $0.14,0.13$. Similarly, relative to the amount of ${ }^{14} \mathrm{C}$ in aspartic acid in the absence of antibiotic (taken as $\mathrm{I}$ ), the following incorporations into the amino acids of the protein of the broken-cell pellet were found: aspartic acid, $\mathrm{I} \cdot 00,0.50$; alanine, I.04, 0.21 ; diaminopimelic acid, 0.I6, 0; glucosamine, 0.14, 0; glutamic acid, 0.55, 0.29; lysine, $0.27,0.29$; serine, $0.22,0.17$; threonine, trace, trace; valine, $0.54,0.15$. The incorporations into the protein of the pellet of broken protozoa were, relative to aspartic acid (taken as I): aspartic acid, I.00; alanine, I.48; diaminopimelic acid, $0 . \mathrm{II}$; glucosamine, 0.29 ; glutamic acid, 0.80; leucine, 0.73; lysine, 0.24; serine, 0.26; threonine, 0.30 ; valine, 0.20. The absence of $\left[{ }^{14} \mathrm{C}\right]$ diaminopimelic acid and $\left[{ }^{14} \mathrm{C}\right]$ glucosamine, constituents of bacterial walls, in the protein fraction of the broken-cell pellet in the presence of ampicillin, shows that incorporation under these conditions was probably into protozoal and not bacterial material. These results show therefore that Epi. ecaudatum caudatum, unlike Ento. caudatum, can synthesize a range of amino acids from glucose.

The ${ }^{14} \mathrm{C}$-material in the 'hot' TCA-soluble fraction of the broken-cell pellet. $\left[{ }^{14} \mathrm{C}\right] \mathrm{glucose}$ was the only labelled compound present after acid hydrolysis (Coleman, I969 $b$ ). As this must have been derived from a glucose polysaccharide, it was important to determine if it was of bacterial or protozoal origin. Attempts to separate protozoal polysaccharide granules from intact bacteria by centrifuging through sucrose, as was done with Ento. caudatum (Coleman, 1969b), were unsuccessful and a method based on the different rates at which bacteria and polysaccharide granules were disrupted by sonication was used. The material was sonicated for $5 \mathrm{~min}$ and then washed into a $15 \mathrm{ml}$ centrifuge tube with water and centrifuged at $740 \mathrm{~g}$ for $10 \mathrm{~min}$. The pellet was washed once in water and plated out for the estimation of ${ }^{14} \mathrm{C}$. To determine the minimum time of 
sonication required to break up the bacteria, ${ }^{14} \mathrm{C}$-labelled bacteria were first prepared from broken Epi. ecaudatum caudatum (ovine) by the method of Coleman (1969b). On sonication of these bacteria for $0, \mathrm{I}, 2 \cdot 5,5,7$ and $\mathrm{romin}, 63,4 \mathrm{I}, 23,9,6$ and $5 \%$, respectively, of the original ${ }^{14} \mathrm{C}$ was present in the washed pellet at the end of the experiment. Starch grains and polysaccharide granules were unaffected by these treatments. A sonication time of $5 \mathrm{~min}$ was adopted and any appreciable amount of ${ }^{14} \mathrm{C}$ found in the washed pellet from the broken-cell pellet of intact protozoa was assumed to be of protozoal origin. In the absence of ampicillin, $38 \%$, and in its presence, $56 \%$ of the glucose polysaccharide was found in the form of protozoal polysaccharide granules, the remainder presumably being bacterial capsular polysaccharide as in Ento. caudatum (Coleman, 1969b). Ampicillin decreased incorporation into the protozoal polysaccharide fraction and into the broken-cell supernatant fluid by $2 \mathrm{I} \%$. Incorporation into the 'hot' TCA-soluble fraction of the sonicated supernatant from the broken-cell pellet was decreased $62 \%$ by ampicillin. These results are interpreted as showing that once the glucose is in the protozoon, ampicillin has no effect on its metabolism to polysaccharide, but that incorporation by bacteria inside or attached to the outside of the protozoa was markedly decreased by the antibiotic.

\section{Source of amino acids for protozoal growth}

To determine the source of amino acids required by Epidinium for growth, the uptake of ${ }^{14} \mathrm{C}$-labelled E. coli and ${ }^{35}$ S-labelled mixed rumen bacteria (Bird, 1972) by a washed suspension of Epi. ecaudatum caudatum (ovine) was compared with that by Ento. caudatum where bacteria are known to be the major source of amino acids (Coleman, 1964, 1967b). In one experiment, in I60 min, each Ento. caudatum engulfed I 500 E. coli or rumen bacteria which contained 0.36 and $0.27 \mathrm{ng}$ protein, respectively. As $65 \%$ of the material in each bacterium was incorporated into the protozoal broken-cell supernatant fluid, the amount of protein in this protozoal fraction was increased by 0.24 and $0.17 \mathrm{ng} /$ protozoon, respectively. Since the broken-cell supernatant fluid contained $0.55 \mathrm{ng}$ protein, it would take $6 . \mathrm{I} \mathrm{h}$ with $E$. coli and $8.6 \mathrm{~h}$ with the rumen bacteria to double the amount of protein in this supernatant, assuming a linear uptake of bacteria with time. As Ento. caudatum divides only every $24 \mathrm{~h}$ this would be more than enough to supply the amino acids required for growth.

In contrast, each Epi. ecaudatum caudatum (ovine) organism which contained I4.2 ng protein in its broken-cell supernatant fluid, took up, in $160 \mathrm{~min}, 2900 \mathrm{E}$. coli $(0.67 \mathrm{ng}$ protein) or 860 rumen bacteria (0. I5 ng protein); approximately $70 \%$ of this bacterial material was found in the broken-cell supernatant fluid. If these bacteria were the only sources of amino acids, the protozoa could divide only every $80 \mathrm{~h}$ (E. coli) or $350 \mathrm{~h}$ (rumen bacteria).

\section{DISCUSSION}

As it is not possible to grow Epidinium spp. without bacteria and complex food materials such as wholemeal flour and dried grass, no direct evidence can be obtained on the source of amino acids for protozoal growth. Although the metabolism of Epidinium spp. grown in vitro may differ from that of the same organisms in the rumen, under both conditions there is a highly reduced environment deficient in readily metabolized substrates but containing bacteria and starch grains as a source of carbohydrate. As Epidinium spp. will grow only under narrowly defined conditions, it is likely that the results obtained in vitro are relevant to conditions in vivo. The only evidence available comes from experiments with washed suspensions of Epidinium where the incorporation of radioactive tracers, e.g. bacteria, into the broken-cell supernatant fluid is measured. It is necessary to measure uptake into this 
fraction rather than into intact protozoa because this supernatant fluid fraction is probably of only protozoal origin, whereas the protozoa have many intact bacteria associated with them. For an Epidinium organism to divide every $24 \mathrm{~h}$, the protein of the broken-cell supernatant fluid must increase by $600 \mathrm{pg} / \mathrm{h}$, assuming that there is no release of protein into the medium as is known to occur. The results show that amino acids can be derived from a number of different sources, although it is not known which, if any, are mutually exclusive. The amount of protein that could be derived/h from the sources given, when present at the concentrations shown, are: E. coli $\left(10^{9} / \mathrm{ml}\right), 180 \mathrm{pg} ; P$. mirabilis $\left(10^{9} / \mathrm{ml}\right), 150 \mathrm{pg}$; Butyrivibrio fibrisolvens $\left(10^{9} / \mathrm{ml}\right), 6 \mathrm{pg}$; rumen bacteria $\left(10^{9} / \mathrm{ml}\right), 37$ to $150 \mathrm{pg}$ (depending on the experiment); soluble material derived from the digestion of $B$. megaterium by the lytic enzyme (I mg/ml), $44 \mathrm{pg}$ (Coleman \& Laurie, I974); glucose (I mM), 20 to $50 \mathrm{pg}$ or (O. I M), 100 to $300 \mathrm{pg}$; glycine (O.I mM), I. 5 to $10.8 \mathrm{pg}$ as glycine only; 20 free amino acids (each at $0 . \mathrm{I} \mathrm{mM}), 20 \times 2.5=50 \mathrm{pg}$; starch (excess) $0.5 \mathrm{I} \mathrm{pg}$. The only sources in the rumen or in culture are bacteria, starch and amino acids at $0 \cdot 1 \mathrm{mM}$ or below. E. coli, B. megaterium and $P$. mirabilis are not found in the rumen, although the last is present in the protozoal cultures. Therefore $\mathrm{I} 50 \mathrm{pg}$ protein $/ \mathrm{h}$ could be derived from $10^{9}$ bacteria (of any type)/ml, a maximum of $50 \mathrm{pg}$ from free amino acids and $\mathrm{I} \mathrm{pg}$ by biosynthesis from starch giving a total of approximately $200 \mathrm{pg}$ protein/h. Under the standard cultural conditions, the Epidinium spp. must divide every 3 days to maintain themselves in the culture, although the minimum generation time measured was I·I days (Coleman et al. 1972). The protein 'uptakes' were therefore just adequate to provide for growth at a slow rate without allowing for the protein lost by the protozoa on incubation in washed suspension. This suggests that the Epidinium spp. may have another source of protein, possibly the wholemeal flour ( $\mathrm{I} \cdot 2 \%$ protein) or dried grass used to feed the cultures. In a standard culture $3000 \mathrm{pg}$ of protein/protozoon (i.e. $125 \mathrm{pg} / \mathrm{h}$ ) would be added each day from the wholemeal flour and much less from the dried grass as very little is taken up by the protozoa.

The Epidinium spp. differed from the Entodinium spp. studied previously (Coleman, 1964, 1972), in that they took up bacteria much less readily on a weight basis. Assuming that the protozoa were cylindrical, the average volumes of an Ento. caudatum organism and an Epidinium sp. organism were 65000 and $360000 \mu \mathrm{m}^{3}$, respectively, showing that there was a 5- to 6-fold difference in volume and a 3 -fold difference in surface area. However, the maximum number of $E$. coli engulfed by a normal, fed protozoon was $2200 / \mathrm{h}$ by Ento. caudatum and $1870 / \mathrm{h}$ by Epi. ecaudatum caudatum (ovine); only with $P$. mirabilis was the uptake of bacteria markedly greater with the Epidinium spp. The maximum volume of medium cleared by each Epidinium or Entodinium/h was also usually in the range of 0.5 to $5.0 \times$ ${ }_{10}{ }^{6} \mu \mathrm{m}^{3}$. Epidinium spp., even in an infinitely dilute suspension of bacteria, cleared a smaller volume of bacteria than comparable free-living organisms, although the number of bacteria engulfed was similar (Curds \& Cockburn, 1968; Proper \& Garver, 1966; Heal, 1967). This may be the result of adaptation to an environment (i.e. the rumen) where food organisms are present at a high population density.

The role of the Epidinium spp. in rumen fermentation depends on the numbers present and, in sheep on pasture, this is often low and very variable between different animals with a B-type population. However, in animals on a restricted high grain ration, Eadie \& Mann (1970) showed that there was a large increase in the number of protozoa present and that Epidinium spp. and Entodinium spp. were the most numerous, with populations of the former of approximately $10^{5} / \mathrm{ml}$. The Epidinium spp. would occupy under these conditions 3 to $4 \%$ of the liquid volume in the rumen, compared with $3 \%$ for Ento. simplex and $3 \%$ for the bacteria. Although these figures are only a rough estimate, they show that Epidinium 
can be very important in the rumen. If each protozoon synthesizes I ng protein/h (in brokencell supernatant fluid and pellet fractions together) then, in a rumen of 21 volume, approximately $5 \mathrm{~g}$ of protein would be synthesized by them each day. If an appreciable amount of this protein is obtained from protein in the feed, then protozoa are important in the prevention of bacterial degradation of protein.

We thank Dr P. Kemp for inserting permanent rumen cannulae into the sheep, and members of the Sub-Department of Chemical Microbiology, Biochemistry Department, University of Cambridge, for helpful advice and criticism.

\section{REFERENCES}

Bailey, R. W. \& Gaillard, B. D. E. (1965). Carbohydrases of the rumen ciliate Epidinium ecaudatum (Crawley). Hydrolysis of plant hemicellulose fractions and $\beta$-linked glucose polymers. Biochemical Journal 95, 758-766.

BIRD, P. R. (1972). Sulphur metabolism and excretion studies in ruminants. 6. The digestibility and utilization by sheep of ${ }^{35} \mathrm{~S}$ from ${ }^{35} \mathrm{~S}$-labelled ruminal microorganisms. Australian Journal of Biological Science 25, 195-203.

Clarke, R. T. J. (1964). Ciliates of the rumen of domestic cattle (Bos taurus L.). New Zealand Journal of Agricultural Research 7, 248-257.

Coleman, G.S. (1956). The dissimilation of amino acids by Rhodospirillum rubrum. Journal of General Microbiology 15, 248-256.

Coleman, G. S. (1964). The metabolism of Escherichia coli and other bacteria by Entodinium caudatum. Journal of General Microbiology 37, 209-223.

Coleman, G. S. (1967a). The metabolism of free amino acids by washed suspensions of the rumen ciliate Entodinium caudatum. Journal of General Microbiology 47, 433-447.

Coleman, G. S. (1967b). The metabolism of the amino acids of Escherichia coli and other bacteria by the rumen ciliate Entodinium caudatum. Journal of General Microbiology 47, 449-464.

Coleman, G. S. (1968). The metabolism of bacterial nucleic acid and of free components of nucleic acid by the rumen ciliate Entodinium caudatum. Journal of General Microbiology 54, 83-96.

Coleman, G. S. (1969a). The cultivation of the rumen ciliate Entodinium simplex. Journal of General Microbiology 57, 81-90.

Coleman, G. S. ( $1969 b$ ). The metabolism of starch, maltose, glucose and some other sugars by the rumen ciliate Entodinium caudatum. Journal of General Microbiology 57, 303-332.

Coleman, G. S. (1972). The metabolism of starch, glucose, amino acids, purines, pyrimidines and bacteria by the rumen ciliate Entodinium simplex. Journal of General Microbiology 71, I 17-13 I.

Coleman, G. S. (1973). The metabolism of bacteria and amino acids by three Epidinium spp. isolated from the rumen and cultured in vitro. Journal of General Microbiology 77, viii.

Colfman, G. S., Davies, J. I. \& Cash, M. A. (1972). The cultivation of the rumen ciliates Epidinium ecaudatum caudatum and Polyplastron multivesiculatum in vitro. Journal of General Microbiology 73, 509-52I.

Coleman, G. S. \& Hall, F. J. (1974). The metabolism of Epidinium ecaudatum caudatum and Entodinium caudatum as shown by autoradiography in the electron microscope. Journal of General Microbiology $85,265-273$.

Coleman, G. S. \& Laurie, J. I. (1974). The utilization of Bacillus megaterium and the release of a lytic enzyme by three Epidinium spp. isolated from the rumen. Journal of General Microbiology 85, 257-264.

Conway, E. J. (1947). Microdiffusion Analysis and Volumetric Error. London: Crosby Lockwood \& Son.

Curds, C. R. \& CockBURN, A. (1968). Studies on the growth and feeding of Tetrahymena pyriformis in axenic and monoxenic culture. Journal of General Microbiology 54, 343-358.

EADIE, J. M. (1962). Inter-relationships between certain rumen ciliate protozoa. Journal of General Microbiology 29, 579-588.

EADIE, J. M. (1967). Studies on the ecology of certain rumen ciliate protozoa. Journal of General Microbiology 49, 175-194.

EADIE, J. M. \& MANN, S. O. (1970). Development of the rumen microbial population: high starch diets and instability. In Physiology of Digestion and Metabolism in the Ruminant, pp. 335-347. Newcastle-uponTyne: Oriel Press. 
Florkin, M. \& Duchateau-Bosson, G. (I943). Forms of uricolytic enzyme systems and the evolution of purine metabolism in the animal kingdom. Archives internationales de physiologie 53, 267-307.

GutierReZ, J. \& Davis, R. E. (1962). Culture and metabolism of the rumen ciliate Epidinium ecaudatum (Crawley). Applied Microbiology ro, 305-308.

HEAL, O. W. (1967). Quantitative studies on soil amoebae. In Progress in Soil Biology, pp. 120-126. Edited by O. Graff and J. E. Satchell. Amsterdam: North Holland Publishing Co.

Lowry, O. M., Rosebrough, N. J., Farr, A. L. \& Randall, R. J. (I95I). Protein measurement with the Folin phenol reagent. Journal of Biological Chemistry 193, 265-275.

OXFoRD, A. E. (1959). Bloat in cattle. I5. Further observations concerning the ciliate Epidinium ecaudatum, an inhabitant of the rumens of cows liable to legume bloat. New Zealand Journal of Agricultural Research 2, 365-374.

Proper, G. \& GARVer, J. C. (1966). Mass culture of the protozoa Colpoda steinii. Biotechnology and Bioengineering 8, 287-296.

WHITE, R. W. (1969). Viable bacteria inside the rumen ciliate Entodinium caudatum. Journal of General Microbiology 56, 403-408.

Wright, D. E. \& HUNGATE, R. E. (1967). Amino acid concentrations in rumen fluid. Applied Microbiology 15, I48-I5I. 